\title{
Methane-Oxidizing Communities in Lichen-Dominated Forested Tundra Are Composed Exclusively of High-Affinity USC $\alpha$ Methanotrophs
}

\author{
Svetlana E. Belova, Olga V. Danilova, Anastasia A. Ivanova, Alexander Y. Merkel \\ and Svetlana N. Dedysh *
}

Winogradsky Institute of Microbiology, Research Center of Biotechnology of the Russian Academy of Sciences, Leninsky Ave. 33/2, Moscow 119071, Russia; svet-bel@mail.ru (S.E.B.); vinnigo@gmail.com (O.V.D.); ivanovastasja@gmail.com (A.A.I.); alexandrmerkel@gmail.com (A.Y.M.)

* Correspondence: dedysh@mail.ru; Tel.: +7-499-135-0389

Received: 20 November 2020; Accepted: 18 December 2020; Published: 21 December 2020

\begin{abstract}
Upland soils of tundra function as a constant sink for atmospheric $\mathrm{CH}_{4}$ but the identity of methane oxidizers in these soils remains poorly understood. Methane uptake rates of -0.4 to $-0.6 \mathrm{mg}$ $\mathrm{CH}_{4}-\mathrm{C} \mathrm{m}^{-2}$ day $^{-1}$ were determined by the static chamber method in a mildly acidic upland soil of the lichen-dominated forested tundra, North Siberia, Russia. The maximal $\mathrm{CH}_{4}$ oxidation activity was localized in an organic surface soil layer underlying the lichen cover. Molecular identification of methanotrophic bacteria based on retrieval of the $p m o A$ gene revealed Upland Soil Cluster Alpha (USC $\alpha$ ) as the only detectable methanotroph group. Quantification of these $p m o A$ gene fragments by means of specific qPCR assay detected $\sim 10^{7}$ pmo $A$ gene copies $\mathrm{g}^{-1}$ dry soil. The $p m o A$ diversity was represented by seven closely related phylotypes; the most abundant phylotype displayed $97.5 \%$ identity to $p m o A$ of Candidatus Methyloaffinis lahnbergensis. Further analysis of prokaryote diversity in this soil did not reveal 16S rRNA gene fragments from well-studied methanotrophs of the order Methylococcales and the family Methylocystaceae. The largest group of reads ( 4\% of all bacterial $16 \mathrm{~S}$ rRNA gene fragments) that could potentially belong to methanotrophs was classified as uncultivated Beijerinckiaceae bacteria. These reads displayed $96-100$ and $95-98 \%$ sequence similarity to $16 \mathrm{~S}$ rRNA gene of Candidatus Methyloaffinis lahnbergensis and "Methylocapsa gorgona" MG08, respectively, and were represented by eight species-level operational taxonomic units (OTUs), two of which were highly abundant. These identification results characterize subarctic upland soils, which are exposed to atmospheric methane concentrations only, as a unique habitat colonized mostly by USC $\alpha$ methanotrophs.
\end{abstract}

Keywords: atmospheric methane oxidation; forested tundra; acidic soils; methanotrophic bacteria; USC $\alpha$ group; $p m o A$ gene; bacterial diversity

\section{Introduction}

Methane $\left(\mathrm{CH}_{4}\right)$ is one of the most impactful greenhouse gases, which has contributed about $20 \%$ of the additional radiative forcing accumulated in the lower atmosphere since 1750 [1-4]. Emissions and concentrations of $\mathrm{CH}_{4}$ are continuing to increase; the current atmospheric $\mathrm{CH}_{4}$ mixing ratio is $1.8 \mathrm{ppmv}$. Major biological net sinks for atmospheric methane are well aerated upland soils [5-7]. Atmospheric $\mathrm{CH}_{4}$ uptake in these soils is due to activity of aerobic methanotrophic bacteria, which utilize methane as a source of energy [8-11]. Aerobic methanotrophs comprise a number of bacterial genera within the Gamma- and Alphaproteobacteria, as well as the Verrucomicrobia [12]. A key enzyme of the methanotrophic metabolism is particulate methane monooxygenase (pMMO), which is present in 
most currently described methanotroph species. Accordingly, the pmoA gene coding for the active-site polypeptide of pMMO is the most frequently used molecular marker in cultivation-independent detection of aerobic methanotrophs [13].

The apparent affinity for $\mathrm{CH}_{4}$ measured for pure cultures of most currently described methanotroph species is in the range of $1-10 \mu \mathrm{m}$, while the respective values determined for upland soils are in the nanomolar range [14]. Microorganisms that are able to oxidize atmospheric $\mathrm{CH}_{4}$, therefore, are often referred to as "high-affinity" methanotrophs. The identity of high-affinity methane oxidizers in terrestrial ecosystems has been the focus of considerable microbiological research. The first evidence that as-yet-uncultivated methanotroph group is involved in atmospheric $\mathrm{CH}_{4}$ oxidation in upland soils was obtained by both labeling phospholipid fatty acids of methanotrophs with ${ }^{14} \mathrm{CH}_{4}$ and analyzing the $p m o A$ gene library [15]. The $p m o A$ sequences retrieved in this study could not be affiliated to any of the earlier described methanotrophs and displayed only a distant relationship to $p m o A$ gene from Methylocapsa acidiphila, an alphaproteobacterium isolated from acidic peat $[16,17]$. This previously unknown group of pmoA sequences, called Upland Soil Cluster Alphaproteobacteria (USC $\alpha$ ) after Knief et al. [18], has been recovered from many acidic and pH-neutral boreal upland soils [18-23]. These bacteria were also identified as the predominant methanotroph group in acidic carbon-poor cryosols at Axel Heiberg Island in the Canadian high Arctic, which were shown to consistently consume atmospheric methane [24].

The exact phylogenetic position of USC $\alpha$ methanotrophs remained unknown for a long time but their tentative affiliation to the alphaproteobacterial family Beijerinckiaceae was suggested by several metagenomic studies [25-27]. Reconstruction of a draft genome of USC $\alpha$ methanotroph enabled the first insights into the metabolic potential and environmental adaptation strategies of these methanotrophs [27]. The use of multilocus sequence analysis suggested placement of the metagenomic assembly obtained in the latter study in the new, Methylocapsa-related genus of the family Beijerinckiaceae, Candidatus Methyloaffinis lahnbergensis.

Recent isolation of a pure culture of the first cultivated member of the USC $\alpha$ clade, strain MG08, provided valuable insights into the physiology and metabolism of these methanotrophs [28]. $\mathrm{CH}_{4}$ oxidation experiments and ${ }^{13} \mathrm{C}$-single cell isotope analyses proved the ability of strain MG08 to grow at atmospheric concentrations of $\mathrm{CH}_{4}$ and to assimilate carbon from both $\mathrm{CH}_{4}$ and $\mathrm{CO}_{2}$. The genome of strain MG08 encodes the serine cycle for assimilation of carbon from $\mathrm{CH}_{4}$ and $\mathrm{CO}_{2}$, and $\mathrm{CO}_{2}$ fixation through the reductive glycine pathway. This strain also fixes $\mathrm{N}_{2}$ and expresses the genes for a high-affinity hydrogenase and carbon monoxide dehydrogenase, suggesting that oxidation of the atmospheric trace gases, $\mathrm{CO}$ and $\mathrm{H}_{2}$, provides additional energy sources [28]. Based on the results of comparative genome analysis, strain MG08 was classified as a member of the genus Methylocapsa and was tentatively named "Methylocapsa gorgona" MG08. Although the PmoA sequence of Methylocapsa gorgona MG08 clusters within the radiation of USC $\alpha$ PmoA clade, it does not correspond to the major group of PmoA sequences, which are most often retrieved from acidic upland soils. The exact diversity range of USC $\alpha$ methanotrophs, therefore, remains unclear.

This study was undertaken in order to extend the currently available information about the phylogenetic diversity of USC $\alpha$ methanotrophs using unique samples of Russian tundra upland soil, where USC $\alpha$ represents the only detectable methanotroph group.

\section{Materials and Methods}

\subsection{Study Site}

Field studies were carried out in July 2014 in the lichen-dominated pine (Pinus sibirica) forest within a permafrost-free zone of tundra near the Nadym town, the Yamalo-Nenetsky Autonomy, North Siberia $\left(65^{\circ} 36^{\prime} 07.1^{\prime \prime} \mathrm{N}, 72^{\circ} 44^{\prime} 39.5^{\prime \prime}\right.$ E) (Figure 1a). The soil vegetation cover was composed of Cladonia and Cetraria species; Vaccinium spp., Ledum palustre, and Polytrichum commune were also present (Figure 1b,c). Analysis of the soil profile revealed the presence of litter, thin organic layer, gray sand, 
and sandy subsoil (Figure 1d). A set of individual soil samples ( 500 g each) was collected over the soil profiles of three sampling plots located on a distance of 20-30 m from each other. The collected soil was transported to the laboratory, homogenized, and frozen for further molecular analyses within 1 day after sampling.

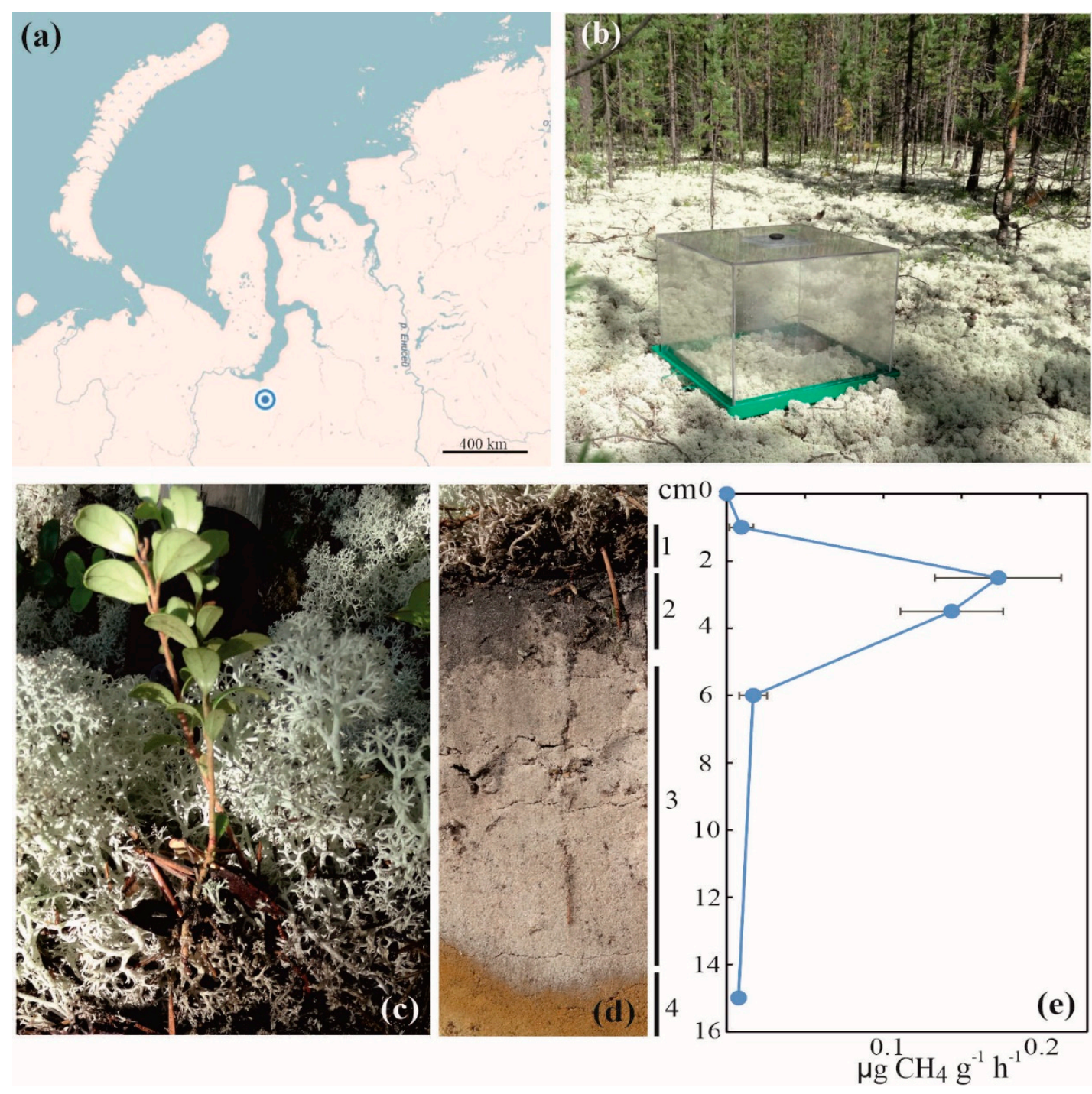

Figure 1. Location and some characteristics of the study site: (a) location of the study site on the map of northern Russia; (b) $\mathrm{CH}_{4}$ flux measurements by static chambers; (c) vegetation cover at the study site; (d) soil profile: 1-litter, 2-organic layer, 3-gray sand, and 4-sandy subsoil; (e) distribution of $\mathrm{CH}_{4}$ oxidation activity over the soil profile.

\subsection{Methane Flux Measurements}

Methane fluxes were measured by the static chamber method [29,30]. Concentration of $\mathrm{CH}_{4}$ in the samples was determined using a Kristall-5000 chromatograph (Khromatek, Yoshkar-Ola, Russia) with a flame ionization detector. Methane flux was calculated in $\mathrm{mg} \mathrm{CH}_{4}-\mathrm{C} \mathrm{m}^{-2} \mathrm{day}^{-1}$.

\subsection{Determination of $\mathrm{CH}_{4}$ Oxidation Activity of Soil Samples}

Methane oxidation rates were determined as described in our previous study [31]. Briefly, weighted portions of wet soil (10 g) sampled from different layers were placed in sterile glass vials $160 \mathrm{~mL}$ in volume, which were then sealed hermetically. Methane was injected in the flasks up to the concentration of about $1000 \mathrm{ppm}$. The vials were incubated at room temperature for $48 \mathrm{~h}$. Samples of 
the gas phase $(0.5 \mathrm{~mL})$ were taken from the flasks periodically and analyzed for methane concentration on a Kristall 5000 chromatograph (Khromatek, Russia). The rate of methane oxidation by the soil samples was calculated in $\mu \mathrm{g} \mathrm{CH}_{4} \mathrm{~g}^{-1}$ of wet soil $\mathrm{h}^{-1}$.

\subsection{Chemical Analysis of the Soil Samples}

The analysis was carried out by certified standard techniques in the analytical center of the MSU Soil Science faculty. The total contents of organic $\mathrm{C}$ and $\mathrm{N}$ in the soil were measured using the vario MACRO Cube analyzer (Elementar Analysensysteme $\mathrm{GmbH}$, Germany). Sulfate concentrations were measured using the Dionex ICS-2000 Ion Chromatography System (Dionex, Sunnyvale, CA, USA). The contents of $\mathrm{Ca}, \mathrm{Mg}, \mathrm{P}$, and Fe were determined by means of inductively coupled plasma mass spectrometry (ICP-MS Agilent 7500a, Agilent, Santa Clara, CA, USA).

\subsection{DNA Extraction, PCR Amplification, and Illumina Sequencing}

Since highest methane oxidation rates were detected in soil collected from the surface organic layer at a depth of $2-5 \mathrm{~cm}$ (see Results), these samples were used for molecular diversity studies. Total DNA extracts were obtained from three individual soil samples ( $\sim .5 \mathrm{~g}$ wet weight) collected from the three sampling plots. The procedure used for DNA extraction and purification is described in our earlier published study [32]. Three DNA extracts were obtained from each soil sample and pooled together for further use in PCR. Fragments of 16S rRNA gene corresponding to the V4 region were PCR-amplified from the DNA samples, purified, and sequenced using the 300PE protocol on MiSeq System (Illumina, USA) as outlined elsewhere [32]. The obtained reads were quality filtered and trimmed using CLC Genomics Workbench 7.5 (Qiagen, Germany), after which overlapping paired-end reads were merged with SeqPrep tool (https://github.com/jstjohn/SeqPrep).

\subsection{Bioinformatic Analysis of Amplicon Sequences}

The 16S rRNA gene reads obtained from the studied soil samples were analyzed with QIIME 2 v.2018.8 (https://qiime2.org) [33]. Sequence quality control, denoising, and chimera filtering were performed by using DADA2 plugin [34]. The reads were clustered into operational taxonomic units (OTUs) by using VSEARCH plugin [35] with open-reference function and Silva v. 132 database [36,37] with $97 \%$ identity.

\subsection{Molecular Identification of Methanotrophic Bacteria}

Total DNA extracted from the soil was used as a template in PCR with the primers A189f (GGNGACTGGGACTTCTTG) and A682r (GAASGCNGAGAAGAASGC) specific to the $p m o A$ gene coding for the active-site polypeptide of particulate methane monooxygenase (pMMO) [38]. DNA from the methanotrophic bacterium Methylocystis heyeri $\mathrm{H}^{\mathrm{T}}$ was used as the positive control. PCR was performed in a PE GeneAmp PCR System 9700 (Perkin-Elmer Applied Biosystems, United States) thermocycler. The reaction mixture contained 0.5-1.0 $\mu \mathrm{L}$ DNA, A189f and A682r primers, $1 \mu \mathrm{L}$ each, $50 \mu \mathrm{L}$ MasterMix (Promega), and sterile water to the total volume of $100 \mu \mathrm{L}$. The thermal profile of the reaction was as follows: initial denaturation $\left(1 \mathrm{~min}\right.$ at $\left.94{ }^{\circ} \mathrm{C}\right) ; 33$ cycles of denaturation $(1 \mathrm{~min}$ at $\left.94{ }^{\circ} \mathrm{C}\right)$, primer annealing $\left(1 \mathrm{~min}\right.$ at $\left.55^{\circ} \mathrm{C}\right)$, and elongation $\left(1 \mathrm{~min}\right.$ at $\left.72^{\circ} \mathrm{C}\right)$, followed by final elongation step $\left(7 \mathrm{~min}\right.$ at $\left.72{ }^{\circ} \mathrm{C}\right)$. PCR products were examined by electrophoresis in $1.2 \%$ agarose gel followed by ethidium bromide staining and visualization of reaction products under a UV transilluminator. Products of three independent reactions obtained with the template DNA of three extracts were pooled together and used for further cloning. Cloning was performed using the pGem-T Easy Vector System II (Promega) according to the manufacturer's recommendations. Recombinant clones were selected using the blue-white screening and screened for the correct insert size (approximately $530 \mathrm{bp}$ ) with vector-specific primers T7 and Sp6 (Promega). Plasmid DNA was purified using a Wizard Plus Minipreps DNA Purification System (Promega). Nucleotide sequences of the cloned DNA fragments 
were determined on an ABI 377A (Perkin-Elmer Applied Biosystems) sequencer. Phylogenetic trees were constructed using the ARB software package [39].

\section{8. qPCR-based Quantification of Methanotrophs}

Quantification of $p m o A$ genes was performed according to a previously described method [40] on a the StepOnePlus ${ }^{\mathrm{TM}}$ Real-Time PCR System (Thermo Fisher Scientific, USA) using qPCRmix-HS SYBR Kit (Evrogen, Russia). Concentration of $p m o A$ genes was estimated using the primer system highly specific to the $p m o A$ sequences retrieved from the examined soil samples at the previous stage. A primer system was designed using Primrose software [41]: pmoA-Cl-F (5'-GCA ATA TGG CAC GCT GAT GT-3') and pmoA-Cl-R (5'-ATG TAT TCG GGC ATC GAG GTA-3'). qPCR thermal program was adjusted experimentally according to the standard protocol: $94^{\circ} \mathrm{C}-20^{\prime \prime} ; 62^{\circ} \mathrm{C}-20^{\prime \prime} ; 72^{\circ} \mathrm{C}-15^{\prime \prime}$; primers conc. $-0.5 \mu \mathrm{M} ; \mathrm{Mg}++$ conc. $-3 \mathrm{mM}$. One of the $p m o A$ amplicons inserted in the $\mathrm{pGEM}^{\circledR}-\mathrm{T}$ vector was used to generate a standard curve. Standards, samples and negative controls were run in triplicate. The correlation coefficient for standard curve was 0.997 .

\subsection{Sequence Accession Numbers}

The $16 \mathrm{~S}$ rRNA gene reads retrieved using Illumina pair-end sequencing from the soil (raw data) have been deposited under the BioProject number PRJNA344855 in the NCBI Sequence Read Archive, with the accession numbers SRX2207619-SRX2207621. Nucleotide sequences of the $p m o A$ gene fragments determined in this study were deposited in GenBank under accession nos. KX534007-KX534056. Identical nucleotide sequences were not deposited.

\section{Results and Discussion}

\subsection{Measurements of $\mathrm{CH}_{4}$ Fluxes}

Measurements of in situ surface $\mathrm{CH}_{4}$ fluxes at the studied forested tundra site in July 2014 showed atmospheric $\mathrm{CH}_{4}$ uptake with rates -0.4 to $-0.6 \mathrm{mg} \mathrm{CH}_{4}-\mathrm{C} \mathrm{m}^{-2}$ day ${ }^{-1}$. These $\mathrm{CH}_{4}$ uptake rates are comparable with those measured at the McGill Arctic Research Station at Expedition Fjord, AHI, Canada ( -0.1 to $-0.8 \mathrm{mg} \mathrm{CH}_{4}-\mathrm{C} \mathrm{m}^{-2}$ day $^{-1}$ ) [24], Quttinirpaaq National Park, Canada ( $-1.37 \pm 0.06 \mathrm{mg}$ $\left.\mathrm{CH}_{4} \mathrm{~m}^{-2} \mathrm{day}^{-1}\right)$ [42], and other terrestrial systems at lower latitudes (-0.1 to $-1.0 \mathrm{mg} \mathrm{CH}_{4}-\mathrm{C} \mathrm{m}^{-2}$ day $\left.^{-1}\right)$ [43].

\subsection{Distribution of Methane Oxidation Activity over the Soil Profile}

Soil profiles in the three sampling plots were highly similar to each other and included litter, thin dark-colored organic layer, gray sand, and sandy subsoil (see 1-4 in Figure 1d). The surface organic layer and the underlying sandy soil displayed a number of contrasting characteristics (Table 1). The former had a pH 4.1, while the latter was nearly neutral (pH 6.1). The content of organic carbon in the surface dark-colored layer was one order of magnitude higher than that in the sandy soil (Table 1). The maximal methane oxidation rates, $0.15-0.18 \mu \mathrm{g} \mathrm{CH}_{4} \mathrm{~g}^{-1} \mathrm{~h}^{-1}$, were detected in samples taken from the organic soil layer, while $\mathrm{CH}_{4}$ oxidation activity in the sandy soil layer was nearly non-measurable (Figure 1e). Further molecular analyses, therefore, were performed with DNA extracts obtained from the surface organic soil layer.

\subsection{Identification and Quantification of Methanotrophs Using pmoA-Based Analysis}

A total of 222 pmoA gene clone sequences were retrieved from the studied DNA extracts. Of these, only 50 nucleotide sequences were unique and were deposited in the GenBank. These 50 sequences represented 7 closely related pmoA phylotypes grouped on the basis of $98 \%$ nucleotide sequence identity (Table 2). 
Table 1. Chemical composition of soil samples.

\begin{tabular}{|c|c|c|c|}
\hline \multicolumn{2}{|c|}{ Parameter } & \multirow{2}{*}{$\begin{array}{c}\text { Organic Layer } \\
1.51 \pm 0.30\end{array}$} & \multirow{2}{*}{$\begin{array}{c}\text { Gray Sand } \\
0.11 \pm 0.02\end{array}$} \\
\hline C org & & & \\
\hline $\mathrm{N}$ total & $\%$ & $0.06 \pm 0.01$ & $0.01 \pm 0.002$ \\
\hline $\mathrm{N}-\mathrm{NO}_{3}$ & & $7.30 \pm 0.55$ & $7.00 \pm 0.53$ \\
\hline $\mathrm{N}-\mathrm{NH}_{4}$ & & $14.00 \pm 1.05$ & $9.00 \pm 0.68$ \\
\hline P total & & $165.0 \pm 33.0$ & $39.0 \pm 7.8$ \\
\hline $\mathrm{SO}_{4}^{2-}$ & $\mathrm{mg} / \mathrm{kg}$ & $19.40 \pm 4.85$ & $1.50 \pm 0.38$ \\
\hline $\mathrm{Ca}$ & & $13600 \pm 2176$ & $440.0 \pm 70.4$ \\
\hline $\mathrm{Mg}$ & & $450.0 \pm 72.0$ & $26.0 \pm 4.16$ \\
\hline $\mathrm{Fe}$ & & $1821.0 \pm 291.0$ & $1621.0 \pm 259.4$ \\
\hline $\mathrm{pH}$ & & $4.1 \pm 0.1$ & $6.1 \pm 0.1$ \\
\hline
\end{tabular}

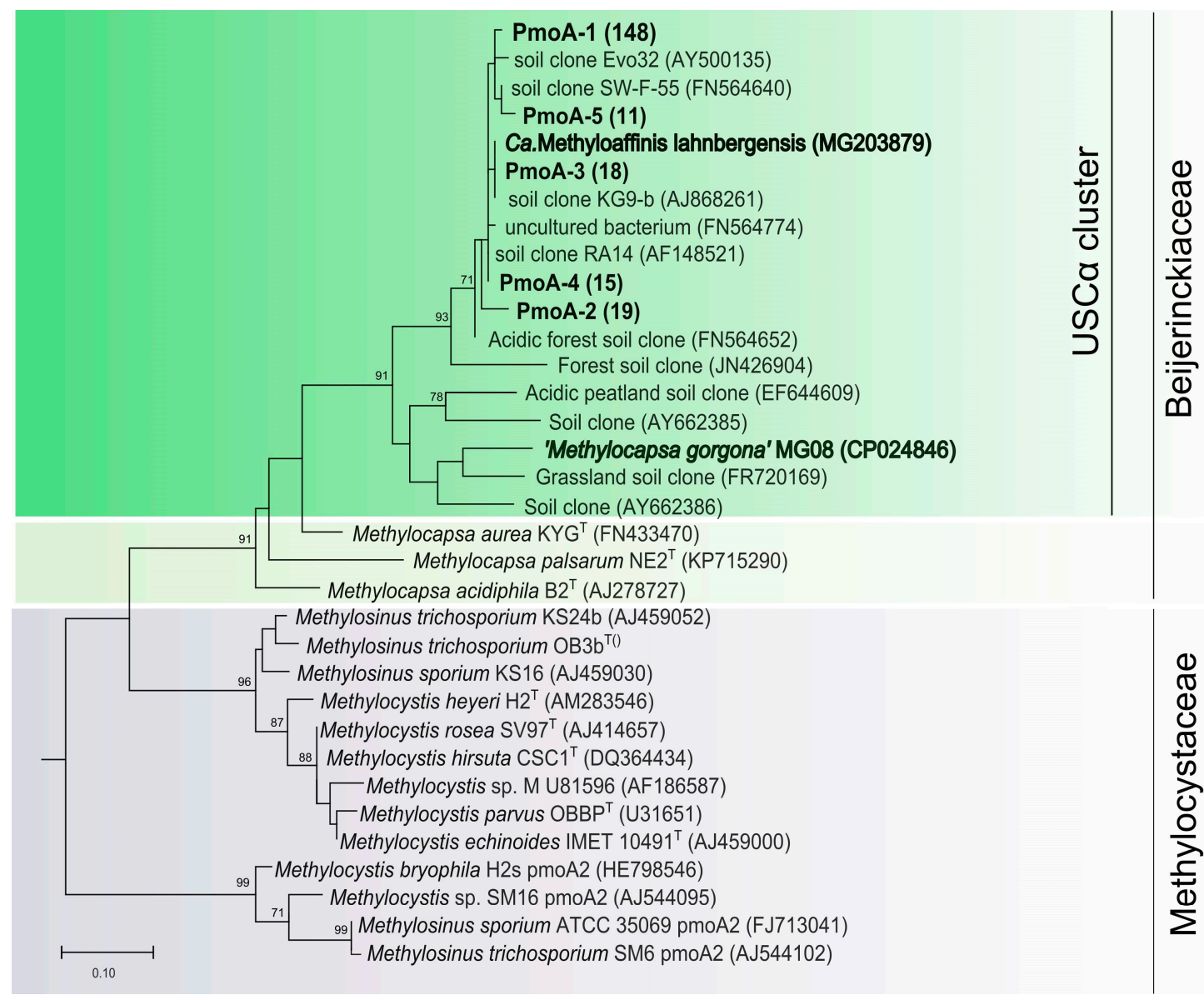

Figure 2. Phylogenetic tree constructed based on 201 amino acid sites of partial PmoA sequences obtained from a forested tundra soil (shown in bold), as well as PmoA from representative members of the families Beijerinckiaceae and Methylocystaceae and some environmental clone sequences. The scale bar corresponds to 0.1 substitutions per amino acid position. 
Table 2. The phylotypes of $p m o A$ gene sequences retrieved from lichen-dominated tundra soil.

\begin{tabular}{|c|c|c|c|c|}
\hline Phylotype & $\begin{array}{l}\text { Number of } \\
\text { Sequences }\end{array}$ & $\begin{array}{l}\text { GenBank } \\
\text { Accession } \\
\text { Numbers }\end{array}$ & $\begin{array}{c}\text { Identity to } \\
\text { Cand. M. } \\
\text { lahnbergensis } \\
(\%)\end{array}$ & $\begin{array}{c}\text { Identity to } M . \\
\text { gorgona }(\%)\end{array}$ \\
\hline pmoA-1* & 148 & $\begin{array}{l}\text { KX534008, } \\
\text { KX534009, } \\
\text { KX534010, } \\
\text { KX534011, } \\
\text { KX534012, } \\
\text { KX534013, } \\
\text { KX534014, } \\
\text { KX534015, } \\
\text { KX534016, } \\
\text { KX534017, } \\
\text { KX534018, } \\
\text { KX534020, } \\
\text { KX534021, } \\
\text { KX534022, } \\
\text { KX534023, } \\
\text { KX534025, } \\
\text { KX534026, } \\
\text { KX534027, } \\
\text { KX534028, } \\
\text { KX534029, } \\
\text { KX534031, } \\
\text { KX534035, } \\
\text { KX534037, } \\
\text { KX534038, } \\
\text { KX534039, } \\
\text { KX534040, } \\
\text { KX534041, } \\
\text { KX534044, } \\
\text { KX534046, } \\
\text { KX534048, } \\
\text { KX534051, }\end{array}$ & 97.5 & 84.2 \\
\hline pmoA-2 * & 19 & $\begin{array}{l}\text { KX534053, } \\
\text { KX534045, } \\
\text { KX534030, } \\
\text { KX534047, } \\
\text { KX534036, } \\
\text { KX534033 }\end{array}$ & 96.4 & 83.1 \\
\hline pmoA-3* & 18 & $\begin{array}{l}\text { KX534034, } \\
\text { KX534049, } \\
\text { KX534019 }\end{array}$ & 99.2 & 83.5 \\
\hline$p m o A-4$ * & 15 & $\begin{array}{l}\text { KX534032, } \\
\text { KX534042 }\end{array}$ & 95.8 & 84.0 \\
\hline$p m o A-5$ * & 11 & KX534043 & 95.0 & 80.8 \\
\hline pmoA-6 & 8 & $\begin{array}{l}\text { KX534007, } \\
\text { KX534054 }\end{array}$ & 96.4 & 83.1 \\
\hline pmoA-7 & 3 & KX534050 & 97.5 & 83.8 \\
\hline
\end{tabular}

* The phylotypes included in the phylogenetic tree (see Figure 2). 
All of them belonged to Beijerinckiaceae methanotrophs and affiliated with the USC $\alpha$ clade (Figure 2). The most abundant phylotype, pmoA-1, was represented by 148 sequences and displayed $97.5 \%$ nucleotide identity to $p m o A$ of Candidatus Methyloaffinis lahnbergensis. If grouped on the basis of $93 \%$ nucleotide sequence identity as recommended by Degelmann et al. (2010) [21], all pmoA sequences obtained in our study belong to one species-level OTU, thus suggesting extremely low methanotroph diversity in the tundra soil.

The pool of $p m o A$ sequences retrieved in this study was used to design the primers for specific detection of the target methanotroph group (see Methods). The qPCR-detected $p m o A$ gene copy numbers were highly similar in all three sampling plots and were within a range of 5.9-8.3 $\times 10^{6}$ copies $^{-1}$ of wet soil or $6.6-9.7 \times 10^{6}$ copies $^{-1}$ of dry soil (given water content of $10.7-14.7 \%$ ). These values fall within the range of USC $\alpha$ pmoA gene numbers reported earlier for various soils exhibiting atmospheric $\mathrm{CH}_{4}$ consumption, $0.9 \times 10^{6}-1.2 \times 10^{8}$ copies per gram of dry soil $[7,21,44,45]$. Highest USC $\alpha$ pmoA gene numbers, $0.3-1.2 \times 10^{8}$ copies per gram of dry soil, have so far been reported for boreal forest soils in Germany [21].

\subsection{Molecular Analysis of Bacterial Diversity in Tundra Soil}

A total of 712,393 partial 16S rRNA gene sequences (mean amplicon length $253 \mathrm{bp}$ ) were retrieved from the examined tundra soil. Of these, 496,695 reads were retained after quality filtering, denoising, and removing chimeras. Predominant prokaryote groups in the communities from three sites were the Acidobacteria $(27.5 \pm 0.1 \%$ of the total number of $16 \mathrm{~S}$ rRNA gene fragments, mean \pm SE), Alphaproteobacteria $(25.2 \pm 1.0 \%)$, Planctomycetes $(12.3 \pm 0.8 \%)$, Actinobacteria $(12.1 \pm 0.9 \%)$, Verrucomicrobia $(9.3 \pm 0.1 \%)$, Gammaproteobacteria $(5.3 \pm 0.7 \%)$, and Deltaproteobacteria $(3.4 \pm 0.2 \%)$ (Figure 3A). Minor bacterial groups included WPS-2, Chloroflexi, Cyanobacteria, Firmicutes, and others.
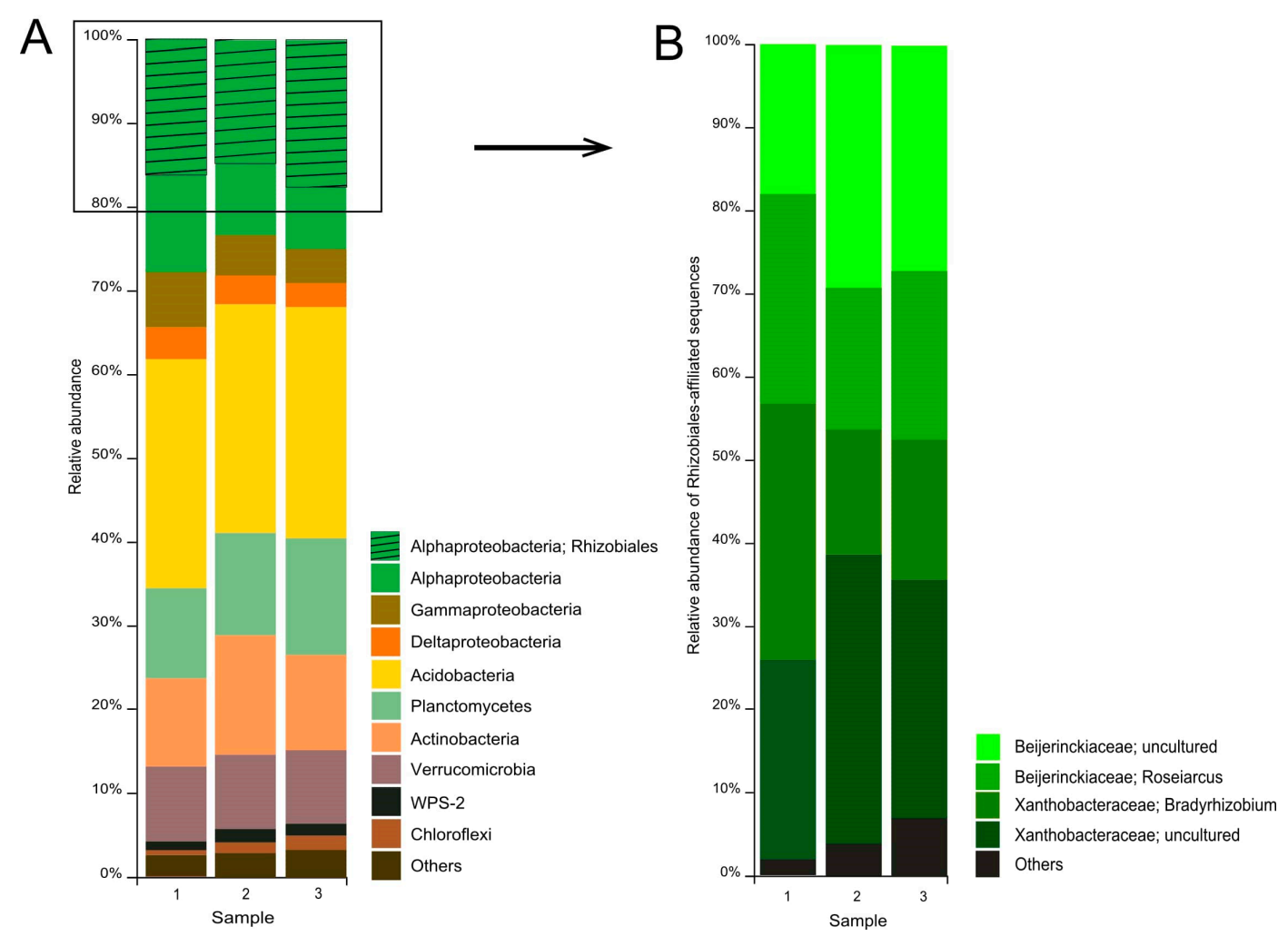

Figure 3. Bacteria community composition in forested tundra soil according to the results of Illumina-based sequencing of $16 \mathrm{~S}$ rRNA genes. The composition is displayed at the (A) phylum level and (B) family level of the alphaproteobacterial order Rhizobiales. 
The largest group among the Alphaproteobacteria was the order Rhizobiales ( $64 \pm 0.7 \%$ of the number of 16S rRNA gene fragments affiliated with the Alphaproteobacteria). Two groups of Rhizobiales-affiliated sequences were represented by reads taxonomically classified within the genera Roseiarcus $(20.8 \pm 1.9 \%$ of all Rhizobiales-affiliated reads) and Bradyrhizobium (20.9 $\pm 4.1 \%$ ) (Figure 3B).

The third group of Rhizobiales-affiliated sequences belonged to uncultured members of the Xanthobacteraceae $(29.2 \pm 2.5 \%)$. Finally, the fourth group of sequences $(25.8 \pm 2.8 \%)$ was identified as belonging to uncultured Beijerinckiaceae. Further analysis of these sequences revealed that they are represented by 8 phylotypes (Table 3).

Table 3. Major operational taxonomic units (OTUs) of $16 \mathrm{~S}$ rRNA gene sequences affiliated with the family Beijerinckiaceae.

\begin{tabular}{|c|c|c|c|c|c|c|}
\hline OTU ID & $\begin{array}{c}\text { Relative } \\
\text { Abundance } \\
(\%)\end{array}$ & Taxonomy & $\begin{array}{c}\text { Closest Silva } \\
\text { Match } \\
\text { (Similarity, \%) }\end{array}$ & $\begin{array}{c}\text { Reported } \\
\text { Habitat }\end{array}$ & $\begin{array}{l}\text { Similarity } \\
\text { MG203879 } \\
(\%)\end{array}$ & $\begin{array}{l}\text { Similarity } \\
\text { M. gorgona } \\
(\%)\end{array}$ \\
\hline $16 \mathrm{~S}-1$ & 2.358 & $\begin{array}{c}\text { Beijerinckiaceae } \\
\text { uncultured }\end{array}$ & $\begin{array}{l}\text { AY913480 } \\
(100)\end{array}$ & bulk soil & 99 & 98.6 \\
\hline $16 \mathrm{~S}-2$ & 1.902 & $\begin{array}{c}\text { Beijerinckiaceae } \\
\text { uncultured }\end{array}$ & $\begin{array}{l}\text { AY913598 } \\
\quad(100)\end{array}$ & $\begin{array}{l}\text { limestone } \\
\text { cave }\end{array}$ & 100 & 97.6 \\
\hline $16 \mathrm{~S}-3$ & 0.167 & Beijerinckiaceae & $\begin{array}{l}\text { KX509291 } \\
(100)\end{array}$ & rainwater & 98.6 & 98.1 \\
\hline $16 S-4$ & 0.021 & Beijerinckiaceae & $\begin{array}{l}\text { KT182565 } \\
(100)\end{array}$ & bioreactor & 96.6 & 96.2 \\
\hline $16 S-5$ & 0.019 & Beijerinckiaceae & JQ905994 (99) & acid mine & 96.6 & 97.1 \\
\hline $16 S-6$ & 0.016 & Beijerinckiaceae & $\begin{array}{l}\text { FPLS01031837 } \\
(100)\end{array}$ & unknown & 98.6 & 98.1 \\
\hline $16 \mathrm{~S}-7$ & 0.01 & Beijerinckiaceae & KF100807 (99) & human skin & 96.6 & 95.7 \\
\hline $16 \mathrm{~S}-8$ & 0.004 & $\begin{array}{c}\text { Beijerinckiaceae } \\
\text { uncultured }\end{array}$ & $\begin{array}{l}\text { HG528987 } \\
\text { (100) }\end{array}$ & peatland & 98.1 & 98.6 \\
\hline
\end{tabular}

Two of these phylotypes, 16S-1 and 16S-2, were most abundant and were represented by 11,712 and 9446 reads, comprising 2.4 and $1.9 \%$ of all bacterial sequences retrieved from the studied soil. Phylotypes 16S-1 and 16S-2 displayed 99 and 100\% sequence similarity to 16S rRNA gene sequence of Candidatus Methyloaffinis lahnbergensis and 98.6 and $97.6 \%$ sequence similarity to $16 \mathrm{~S}$ rRNA gene sequence of "Methylocapsa gorgona" MG08, respectively (Table 3, Figure 4).

Notably, no 16S rRNA gene fragments from well-studied methanotrophs of the order Methylococcales and the family Methylocystaceae were detected within the pool of reads retrieved in our study, which fully corresponds to the results of pmoA-based diversity analysis.

The results obtained in our study, therefore, characterize subarctic sandy upland soils as a unique habitat colonized mostly or exclusively by USC $\alpha$ methanotrophs. As shown by the recent 16S rRNA gene-based environmental distribution survey of USC $\alpha$ methanotrophs [27], arctic and subarctic soils are among the major habitats of these bacteria. The ecological advantage of USC $\alpha$ members over other methanotrophs, most likely, is explained by the fact that these soils, in contrast to arctic wetlands and boreal upland soils, are exposed to atmospheric methane concentrations only. While arctic wetlands may emit methane, arctic desert soils function as a constant sink for atmospheric $\mathrm{CH}_{4}$ [42]. One of our previous studies on methanotroph diversity was performed in a subarctic wetland with mosaic cover of Sphagnum mosses and lichens [31]. This wetland is in a close proximity to the study site examined in this work (a distance of $14.5 \mathrm{~km}$ ). While USC $\alpha$ methanotrophs were also detected in that subarctic wetland, the indigenous methanotroph community was by far more diverse and included conventional type I and type II methanotrophs as well [31]. Interestingly, members of the genera Methylocystis and Methylosinus, which contain Pmo2 enzyme catalyzing oxidation of $\mathrm{CH}_{4}$ at atmospheric levels [46-48] and are commonly detected in upland boreal soils $[5,7,18,21]$, were absent from the studied tundra 
soil. As suggested earlier, these methanotrophs cannot sustain activity and growth on atmospheric methane alone, and their long-term survival depends on availability of methane produced in anaerobic micro-sites of upland soils [5]. Such an in situ methane production does not occur in well-aerated sandy soils examined in this study and, therefore, Pmo2-possessing Methylocystis and Methylosinus species cannot compete with USC $\alpha$ methanotrophs for colonizing this niche.

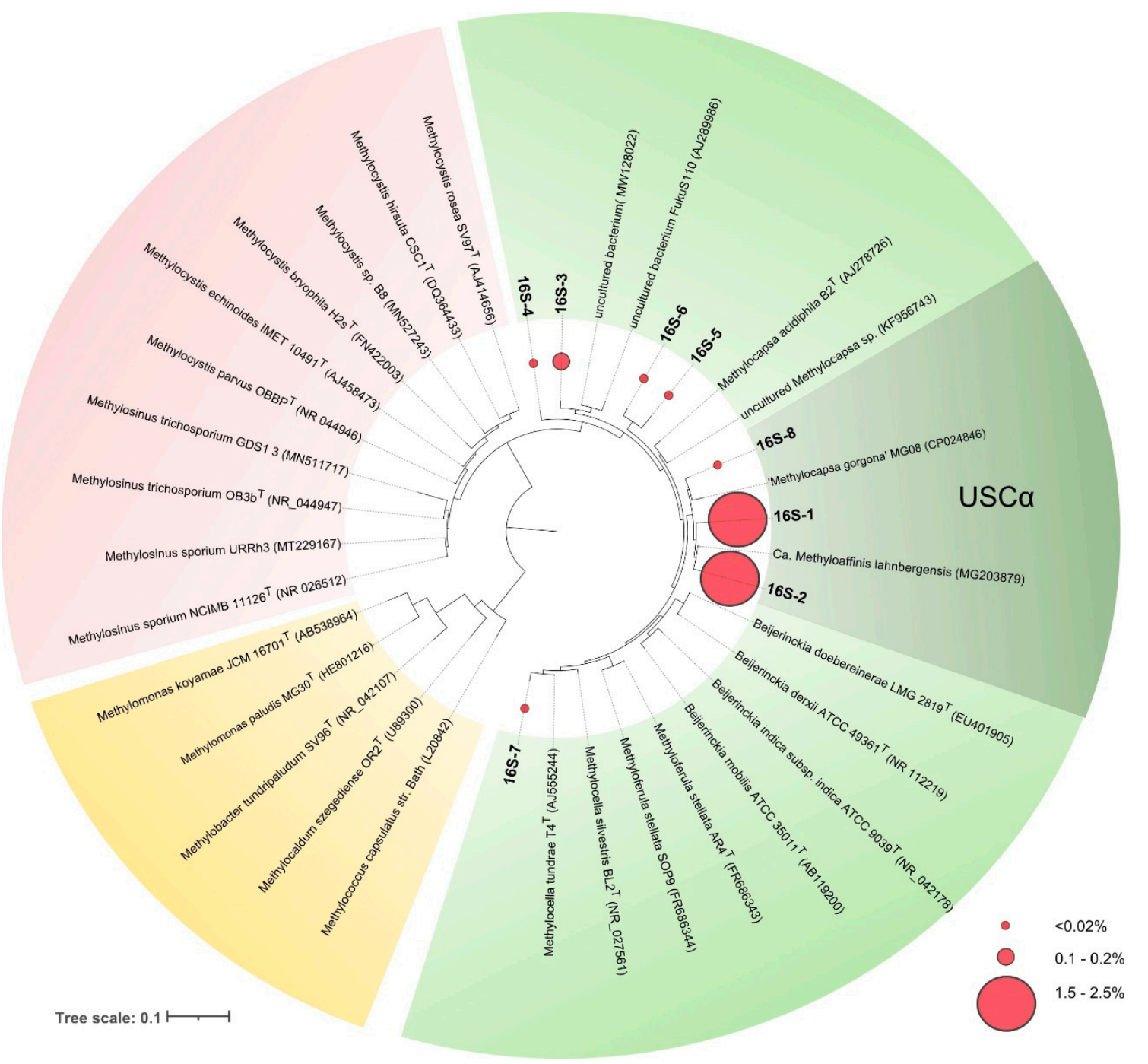

Figure 4. 16S rRNA gene-based maximum-likelihood tree showing the phylogenetic position of sequences retrieved from acidic tundra soil in relation to Candidatus Methyloaffinis lahnbergensis, "Methylocapsa gorgona" MG08 and some representatives of the family Beijerinckiaceae (shown in green), Methylocystaceae (red), and Methylococcaceae (yellow). Red circles of different sizes show relative abundances of the corresponding OTUs. The scale bar corresponds to 0.1 substitutions per nucleotide position.

As seen from Figure 2, most methanotrophs detected in lichen-dominated tundra soil were closely related to Candidatus Methyloaffinis lahnbergensis [27] and not to "Methylocapsa gorgona" MG08 [28]. Although phylogenetically close, these methanotrophs may possess some differences in physiology and adaptation potential, which are reflected in their distribution pattern. Isolation of Candidatus Methyloaffinis-like bacteria remains one of the key challenges in methanotroph cultivation and subarctic sandy soils are one of the promising sources for these isolation studies. 
In summary, our study showed that upland soils of a lichen-dominated forested tundra function as a sink for atmospheric $\mathrm{CH}_{4}$. Methane-oxidizing communities in these soils are composed exclusively of high-affinity USC $\alpha$ methanotrophs, which are localized in a very thin organic surface soil layer underlying the lichen cover. Possible disturbances of this surface soil layer due to anthropogenic activities may result in degradation of this fragile methane-oxidizing microbial filter and loss of its function.

Author Contributions: Conceptualization, S.N.D.; investigation, S.E.B., O.V.D., and A.Y.M.; data curation, A.A.I. and A.Y.M.; writing—original draft preparation, S.E.B., A.Y.M., and S.N.D.; writing—review and editing, S.N.D. All authors have read and agreed to the published version of the manuscript.

Funding: This work was supported by the Ministry of Science and Higher Education of the Russian Federation.

Acknowledgments: The authors are grateful to Irina Gagarinova (Center for Arctic Research, Nadym) for her help in the field.

Conflicts of Interest: The authors declare no conflict of interest.

\section{References}

1. Dlugokencky, E.J; Nisbet, E.G.; Fisher, R.; Lowry, D. Global atmospheric methane: Budget, changes and dangers. Philos. Trans. R. Soc. A Math. Phys. Eng. Sci. 2011, 369, 2058-2072. [CrossRef] [PubMed]

2. Kirschke, S.; Bousquet, P.; Ciais, P.; Saunois, M.; Canadell, J.G.; Dlugokencky, E.J.; Bergamaschi, P.; Bergmann, D.; Blake, D.R.; Bruhwiler, L.; et al. Three decades of global methane sources and sinks. Nat. Geosci. 2013, 6, 813-823. [CrossRef]

3. Ciais, P.; Sabine, C.; Bala, G.; Bopp, L.; Brovkin, V.; Canadell, J.; Chhabra, A.; DeFries, R.; Galloway, J.; Heimann, M.; et al. Carbon and other biogeochemical cycles. In Climate Change 2013 the Physical Science Basis: Working Group I Contribution to the Fifth Assessment Report of the Intergovernmental Panel on Climate Change; Stocker, T.F., Qin, D., Plattner, G.-K., Tignor, M., Allen, S.K., Boschung, J., Nauels, A., Xia, Y., Bex, V., Midgley, P.M., Eds.; Cambridge University Press: Cambridge, UK, 2013; pp. 465-570.

4. Prather, M.J.; Holmes, C.D. Overexplaining or underexplaining methane's role in climate change. Proc. Natl. Acad. Sci. USA 2017, 114, 5324-5326. [CrossRef] [PubMed]

5. Dunfield, P.F. The soil methane sink. In Greenhouse Gas Sinks; Reay, D.S., Hewitt, C.N., Smith, K.A., Grace, J., Eds.; CABI: Wallingford, UK, 2007; pp. 152-170.

6. Shallcross, D.E.; Butenhoff, C. The atmospheric methane sink. In Greenhouse Gas Sinks; Reay, D.S., Hewitt, C.N., Smith, K.A., Grace, J., Eds.; CABI: Wallingford, UK, 2007; pp. 171-184.

7. Kolb, S. The quest for atmospheric methane oxidizers in forest soils. Environ. Microbiol. Rep. 2009, 1, 336-346. [CrossRef] [PubMed]

8. Hanson, R.S.; Hanson, T.E. Methanotrophic bacteria. Microbiol. Rev. 1996, 60, 439-471. [CrossRef] [PubMed]

9. Trotsenko, Y.A.; Murrell, J.C. Metabolic aspects of aerobic obligate methanotrophy. Adv. Appl. Microbiol. 2008, 63, 183-229.

10. Chistoserdova, L.; Lidstrom, M.E. Aerobic methylotrophic prokaryotes. In The Prokaryotes: Prokaryotic Physiology and Biochemistry; Rosenberg, E., Delong, E., Lory, S., Stackebrandt, E., Thompson, F., Eds.; Springer-Verlag: Berlin/Heidelberg, Germany, 2013; pp. 267-285.

11. Khmelenina, V.N.; Colin Murrell, J.; Smith, T.J.; Trotsenko, Y.A. Physiology and biochemistry of the aerobic methanotrophs. In Aerobic Utilization of Hydrocarbons, Oils, and Lipids; Rojo, F., Ed.; Springer: Cham, Switzerland, 2019; pp. 1-25.

12. Dedysh, S.N.; Knief, C. Diversity and phylogeny of described aerobic methanotrophs. In Methane Biocatalysis: Paving the Way to Sustainability; Kalyuzhnaya, M.G., Xing, X.-H., Eds.; Springer: Cham, Switzerland, 2018; pp. 17-42.

13. Knief, C. Diversity and habitat preferences of cultivated and uncultivated aerobic methanotrophic bacteria evaluated based on pmoA as molecular marker. Front. Microbiol. 2015, 6, 1346. [CrossRef]

14. Bender, M.; Conrad, R. Kinetics of $\mathrm{CH} 4$ oxidation in oxic soils exposed to ambient air or high $\mathrm{CH} 4$ mixing ratios. FEMS Microbiol. Lett. 1992, 101, 261-270. [CrossRef] 
15. Holmes, A.J.; Roslev, P.; McDonald, I.R.; Iversen, N.; Henriksen, K.; Murrell, J.C. Characterization of methanotrophic bacterial populations in soils showing atmospheric methane uptake. Appl. Environ. Microbiol. 1999, 65, 3312-3318. [CrossRef]

16. Dedysh, S.N.; Horz, H.P.; Dunfield, P.F.; Liesack, W. A novel pmoA lineage represented by the acidophilic methanotrophic bacterium Methylocapsa acidiphila [correction of acidophila] B2. Arch. Microbiol. 2001, 177, 117-121. [CrossRef]

17. Dedysh, S.N.; Khmelenina, V.N.; Suzina, N.E.; Trotsenko, Y.A.; Semrau, J.D.; Liesack, W.; Tiedje, J.M. Methylocapsa acidiphila gen. nov., sp. nov., a novel methane-oxidizing and dinitrogen-fixing acidophilic bacterium from Sphagnum bog. Int. J. Syst. Evol. Microbiol. 2002, 52, 251-261. [CrossRef] [PubMed]

18. Knief, C.; Lipski, A.; Dunfield, P.F. Diversity and activity of methanotrophic bacteria in different upland soils. Appl. Environ. Microbiol. 2003, 69, 6703-6714. [CrossRef] [PubMed]

19. Henckel, T.; Jäckel, U.; Schnell, S.; Conrad, R. Molecular analyses of novel methanotrophic communities in forest soil that oxidize atmospheric methane. Appl. Environ. Microbiol. 2000, 66, 1801-1808. [CrossRef] [PubMed]

20. Jensen, S.; Holmes, A.J.; Olsen, R.A.; Murrell, J.C. Detection of methane oxidizing bacteria in forest soil by monooxygenase PCR amplification. Microb. Ecol. 2000, 39, 282-289. [PubMed]

21. Degelmann, D.M.; Borken, W.; Drake, H.L.; Kolb, S. Different atmospheric methane-oxidizing communities in european beech and norway spruce soils. Appl. Environ. Microbiol. 2010, 10, 3228-3235. [CrossRef]

22. Dörr, N.; Glaser, B.; Kolb, S. Methanotrophic communities in brazilian ferralsols from naturally forested, afforested, and agricultural sites. Appl. Environ. Microbiol. 2010, 76, 1307-1310. [CrossRef]

23. Martineau, C.; Pan, Y.; Bodrossy, L.; Yergeau, E.; Whyte, L.G.; Greer, C.W. Atmospheric methane oxidizers are present and active in Canadian high Arctic soils. FEMS Microbiol. Ecol. 2014, 89, 257-269. [CrossRef]

24. Lau, M.C.Y.; Stackhouse, B.T.; Layton, A.C.; Chauhan, A.; Vishnivetskaya, T.A.; Chourey, K.; Ronholm, J.; Mykytczuk, N.C.S.; Bennett, P.C.; Lamarche-Gagnon, G.; et al. An active atmospheric methane sink in high Arctic mineral cryosols. ISME J. 2015, 9, 1880-1891. [CrossRef]

25. Ricke, P.; Kolb, S.; Braker, G. Application of a newly developed ARB software-integrated tool for in silico terminal restriction fragment length polymorphism analysis reveals the dominance of a novel $p m o A$ cluster in a forest soil. Appl. Environ. Microbiol. 2005, 71, 1671-1673. [CrossRef]

26. Singleton, C.M.; McCalley, C.K.; Woodcroft, B.J.; Boyd, J.A.; Evans, P.N.; Hodgkins, S.B.; Chanton, J.P.; Frolking, S.; Crill, P.M.; Saleska, S.R.; et al. Methanotrophy across a natural permafrost thaw environment. ISME J. 2018, 12, 2544-2558. [CrossRef]

27. Pratscher, J.; Vollmers, J.; Wiegand, S.; Dumont, M.G.; Kaster, A.K. Unravelling the identity, metabolic potential and global biogeography of the atmospheric methane-oxidizing upland soil cluster $\alpha$. Environ. Microbiol. 2018, 20, 1016-1029. [CrossRef] [PubMed]

28. Tveit, A.T.; Hestnes, A.G.; Robinson, S.L.; Schintlmeister, A.; Dedysh, S.N.; Jehmlich, N.; von Bergen, M.; Herbold, C.; Wagner, M.; Richter, A.; et al. Widespread soil bacterium that oxidizes atmospheric methane. Proc. Natl. Acad. Sci. USA 2019, 10, 589. [CrossRef] [PubMed]

29. Glagolev, M.; Kleptsova, I.; Filippov, I.; Maksyutov, S.; MacHida, T. Regional methane emission from West Siberia mire landscapes. Environ. Res. Lett. 2011, 6, 045214. [CrossRef]

30. Glagolev, M.V.; Sabrekov, A.F.; Kleptsova, I.E.; Filippov, I.V.; Lapshina, E.D.; Machida, T.; Maksyutov, S.S. Methane emission from bogs in the subtaiga of Western Siberia: The development of standard model. Eurasian Soil Sci. 2012, 45, 947-957. [CrossRef]

31. Danilova, O.V.; Belova, S.E.; Gagarinova, I.V.; Dedysh, S.N. Microbial community composition and methanotroph diversity of a subarctic wetland in Russia. Microbiology 2016, 85, 583-591. [CrossRef]

32. Ivanova, A.A.; Kulichevskaya, I.S.; Merkel, A.Y.; Toshchakov, S.V.; Dedysh, S.N. High diversity of Planctomycetes in soils of two lichen-dominated sub-arctic ecosystems of northwestern Siberia. Front. Microbiol. 2016, 7, 2065. [CrossRef]

33. Caporaso, J.; Kuczynski, J.; Stombaugh, J. QIIME allows analysis of high-throughput community sequencing data. Nat. Methods 2010, 7, 335-336. [CrossRef]

34. Callahan, B.J.; McMurdie, P.J.; Rosen, M.J.; Han, A.W.; Johnson, A.J.A.; Holmes, S.P. DADA2: High-resolution sample inference from Illumina amplicon data. Nat. Methods 2016, 13, 581-583. [CrossRef]

35. Rognes, T.; Flouri, T.; Nichols, B.; Quince, C.; Mahé, F. VSEARCH: A versatile open source tool for metagenomics. PeerJ 2016, 4, e2584. [CrossRef] 
36. Quast, C.; Pruesse, E.; Yilmaz, P.; Gerken, J.; Schweer, T.; Yarza, P.; Peplies, J.; Glöckner, F.O. The SILVA ribosomal RNA gene database project: Improved data processing and web-based tools. Nucleic Acids Res. 2013, 41, D590-D596. [CrossRef]

37. Glöckner, F.O.; Yilmaz, P.; Quast, C.; Gerken, J.; Beccati, A.; Ciuprina, A.; Bruns, G.; Yarza, P.; Peplies, J.; Westram, R.; et al. 25 years of serving the community with ribosomal RNA gene reference databases and tools. J. Biotechnol. 2017, 261, 169-176. [CrossRef] [PubMed]

38. Holmes, A.J.; Costello, A.; Lidstrom, M.E.; Murrell, J.C. Evidence that participate methane monooxygenase and ammonia monooxygenase may be evolutionarily related. FEMS Microbiol. Lett. 1995, 132, 203-208. [CrossRef] [PubMed]

39. Ludwig, W.; Strunk, O.; Westram, R.; Richter, L.; Meier, H.; Yadhukumar, A.; Buchner, A.; Lai, T.; Steppi, S.; Jacob, G.; et al. ARB: A software environment for sequence data. Nucleic Acids Res. 2004, 32, 1363-1371. [CrossRef]

40. Kubista, M.; Andrade, J.M.; Bengtsson, M.; Forootan, A.; Jonák, J.; Lind, K.; Sindelka, R.; Sjöback, R.; Sjögreen, B.; Strömbom, L.; et al. The real-time polymerase chain reaction. Mol. Aspects Med. 2006, 2-3, 95-125. [CrossRef] [PubMed]

41. Ashelford, K.E.; Weightman, A.J.; Fry, J.C. Primrose: A computer program for generating and estimating the phylogenetic range of $16 \mathrm{~S}$ rRNA oligonucleotide probes and primers in conjunction with the RDP-II database. Nucleic Acids Res. 2002, 30, 3481-3489. [CrossRef]

42. Emmerton, C.A.; St. Louis, V.L.; Lehnherr, I.; Humphreys, E.R.; Rydz, E.; Kosolofski, H.R. The net exchange of methane with high Arctic landscapes during the summer growing season. Biogeosciences 2014, 11, 3095-3106. [CrossRef]

43. Luo, G.J.; Kiese, R.; Wolf, B.; Butterbach-Bahl, K. Effects of soil temperature and moisture on methane uptake and nitrous oxide emissions across three different ecosystem types. Biogeosciences 2013, 10, 3205-3219. [CrossRef]

44. Kolb, S.; Knief, C.; Dunfield, P.F.; Conrad, R. Abundance and activity of uncultured methanotrophic bacteria involved in the consumption of atmospheric methane in two forest soils. Environ. Microbiol. 2005, 7, 1150-1161. [CrossRef]

45. Pratscher, J.; Dumont, M.G.; Conrad, R. Assimilation of acetate by the putative atmospheric methane oxidizers belonging to the USC $\alpha$ clade. Environ. Microbiol. 2011, 13, 2692-2701. [CrossRef]

46. Dunfield, P.F.; Yimga, M. Isolation of a Methylocystis strain containing a novel pmoA-like gene. FEMS Microbiol. Ecol. 2002, 41, 17-26. [CrossRef]

47. Knief, C.; Dunfield, P.F. Response and adaptation of different methanotrophic bacteria to low methane mixing ratios. Environ. Microbiol. 2005, 7, 1307-1317. [CrossRef] [PubMed]

48. Baani, M.; Liesack, W. Two isozymes of particulate methane monooxygenase with different methane oxidation kinetics are found in Methylocystis sp. strain SC2. Proc. Natl. Acad. Sci. USA 2008, 105, 10203-10208. [CrossRef] [PubMed]

Publisher's Note: MDPI stays neutral with regard to jurisdictional claims in published maps and institutional affiliations.

(C) 2020 by the authors. Licensee MDPI, Basel, Switzerland. This article is an open access article distributed under the terms and conditions of the Creative Commons Attribution (CC BY) license (http://creativecommons.org/licenses/by/4.0/). 